Of the recurrent income of $£ 104,441,063$ ( $£ 86,402,542$ in 1962-63), $£ 74,500,135$ was from Treasury grants $(70.5$ per cent) and $£ 888,277$ from grants from Government departments; $£ 9,156,682$ (8.8 por cent) from fees; $£ 2,188,214(2 \cdot 1$ per cent) from endowments; $£ 1,734,077$ ( $1 \cdot 7$ per cont) from local authority grants; $£ 520,699$ from donations and subscriptions; and £12,043,222 (11.5 per cent) from payments for research. For English, Welsh and Scottish institutions the respective total incomes wore: $£ 83,656,716, £ 5,668,742$, and $£ 15,115,605$. Nonrecurrent Treasury grants totalled $£ 43,295,545$ ( $£ 36,481,424$ in $1962-63$ ), and of this $£ 26,869,345$ was in respect of building work, $£ 4,133,745$ professional fees, $£ 10,334,363$ furniture and equipment, and $£ 1,958,092$ purchases of sites and property. Sinco 1952, grants for furniture and equipment have been confined to new accommodation, including buildings adapted for new purposes. Of the recurrent expenditure of $£ 102,301,794,6 \cdot 7$ per cent was on administration, 43.4 per cent on salaries and superannuation of teaching staff, $12 \cdot 1$ per cent on dopartmental wages (technicians and laboratory assistants), $16 \cdot 6$ per cent on departmontal and laboratory maintenance, 2.9 per cont on repairs and maintenance of buildings, and $11 \cdot 1$ per cent on rates, insurance, heat, light, water, etc. Of the expenditure of $£ 3,946,646$ on libraries, $£ 2,093,719$ was on salaries and wages, etc., of staff, and only $£ 957,017$ on books and $£ 461,855$ on periodicals; only London $(£ 155,596)$, Oxford ( $\$ 106,421)$, Cambridge ( $£ 71,074)$ and Leeds ( $£ 61,840$ ) spent more than $£ 50,000$ on books, and only London ( $£ 115,663)$, Cambridge $(£ 35,407)$, Oxford $(£ 34,570)$, Edinburgh $(£ 23,291)$ and Glasgow $(£ 20,553)$ more than $£ 20,000$ on periodicals.

\title{
EMPLOYMENT OF GRADUATES IN BIOLOGICAL SUBJECTS 1962/63
}

$\mathrm{W}$ HILE covering much of the ground dealt with in its first report, the recently published second annual report (1962-63) of the University Grants Committee on the first employment of university graduates* includes an analysis of the employment of men and womon who have graduated with Masters' or Doctors' degrees by thesis and/or cxamination (Table 1).

Table 1. Huployment of Graddates in Brolocical SubJects (1962-63)

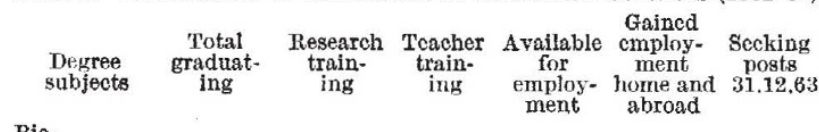

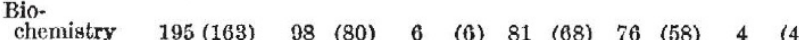

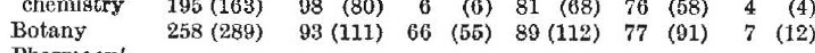

Pharmacy/

pharma-

Physiology

and/or

anatomy $\quad 386(336) \quad 76 \quad(52) \quad 6 \quad(4) \quad 33 \quad(25) \quad 30 \quad(15) \quad 1 \quad(3)$

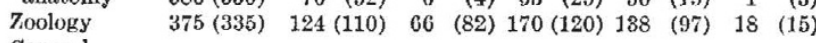

General

biology $\quad 248(264) \quad 19 \quad(31) \quad 74 \quad(70) 128(125) 103(101) \quad 12 \quad(11)$ Agriculture $\quad 345(393) \quad 98(105) \quad 11 \quad(10) 192(122) 163(193) \quad 19 \quad(27)$

Totals 2,085(2,030) 562(525) $229(227) 902(892) 792(754) \quad 62$ (74)

Table 1, abstracted by A. C. Simpson from the two reports (the 1961-62 figures being givon in brackets), shows surprising differences betweon the various sections of biology when the figures for the two years are compared. Thus, while the numbers graduating in zoology and biochemistry increased 12 per cont and 20 per cent, respectively, tho numbers graduating in botany and agriculture decreased by 10 per cent and 12 per cent. Howevor, the number of zoology graduates going on to toncher training fell by 20 per cent while the number of botanists increased by 20 per cont. To tho numbors of graduates that wero still seoking employment 6 months after graduating, the figure for all biologists covered by Table 1 for $1962 / 3$ was 3.0 per cont of thoso graduating compared with $2 \cdot 5$ por cent for chemists and 1.8 per cont for physicists. The figure is not so satisfactory when those continuing study are excluded and the numbers available for employment in the various sections of biology are considored separately; for botany, zoology and general biology respectively, the percentages of those available for employment who wero still seeking employment were 8 por cent, 11 per cent and 9 per cent, respectively. On the other hand, only two of the 434 biologists graduating with higher degrees failod to get omploymont within six months of graduation.

Table 2 gives an analysis of the employment categories of men and women who qualified for first and higher degrees in biochemistry, botany and zoology in 1962/63 and obtained employment in Britain.

Table 2. GRADUATES IN BIOCHEMISTRY, BOTANY AND ZOOLOGY WHO OBTAINED EMPLOYMENT IN BRITAIN (1962-63) Degree: $\begin{aligned} & \text { Biochemistry Botany Zoology Totals } \\ & \text { First Higher First Higher First Higher First Higher }\end{aligned}$

Civil service

Local government

Universities and

Sehools (excluding

those having taken

$\begin{array}{llllllllll}\text { those having taken } & & & & 26 & 9 & 37 & 4 & 70 & 13\end{array}$

Tndustry and com-

$\begin{array}{lllllllll}\text { merce } & 13 & 8 & 14 & 5 & 13 & 2 & 40 & 15\end{array}$

merce

\begin{tabular}{rrrrrrrr}
13 & 8 & 14 & 5 & 13 & 2 & 40 & 15 \\
8 & 4 & 6 & 1 & 18 & 3 & 32 & 8 \\
\hline 73 & 40 & 76 & 52 & 128 & 49 & 277 & 141
\end{tabular}

It is seen that more than half those employed who obtained higher degrees in biochemistry, botany or zoology found thoir first employment within the universities and technical colleges, that schools took on 70 graduates immediately after their first degrees, apart from the 138 who wont into toachor training courses with biochemistry, botany and zoology degrees, and that industry and commerce took nearly three times as many graduatos straight from thoir first degrees than straight after taking higher degrees.

* J. Inst. Biol., 13, Yo. 3 (1965).

\section{SCIENTIFIC POLICY IN BELGIUM}

T HE fifth annual roport of tho National Council for Scientific Policy, Belgium, covers the activities of the Council during 1964*. Its soven chapters review in succession the dovolopmont of scientific policy at the national and international level; the budget for science; the organization of resoarch; the expansion of higher education; the sciontific establishments of the State the distribution of scientific manpower; and the level of

* Conscil National de la Politique Scientifiqne. Rapport Annuel, 1964 Pp. 200. (Bruxelles: Conseil National de la Politlque Sclentifique, 1965,) scientifie potential in 1961. Roports or recommendations were presentod to the Government on the expansion or adaptation of higher education at university lovel; the State sciontific ostablishments and services; the development and finance of nuclear research; the status of the toaching hospitals; and the budget for science for 1965 . At tho international lovel, besides investigating the struclure of scientific policy, the Council was concerned with the support of Euratom and the European Space Research Organization. The budget for science bas 